\title{
The Accidental Optimization Booster
}

\section{SOCIAL SECURITY BENEFITS CAN HAVE SURPRISING VALUE FOR WEALTHY CLIENTS}

\section{By Ed McCarthy}

Planning for Social Security retirement benefits has become a cottage industry, with financial advisers and software developers offering to help retirees increase their benefits. It's certainly sensible for most retirees to maximize what they can earn from the system, but does it matter to the very wealthy?

Consider the example of one such client who easily Although Social Security's retirement benefits are only a small fraction of wealthy retirees' incomes, most advisers report clients are interested in benefit optimization.

In some cases, an optimized strategy can provide a married couple over $\$ 200,000$ more in lifetime benefits compared with a suboptimal strategy.

Research shows that most retirees, including most singles, benefit from delaying the start of their Social Security retirement benefit.

enjoyed "blowing it" That attitude didn't completely surprise Sachs, who notes that at some point the extra monthly income becomes meaningless. "By definition, if you're high net worth, the benefit that you're getting through Social Security is just a complete non-issue," he says. "It doesn't make or break or change one iota one way or the other."

Sachs doesn't tell clients to waste the money, but he does believe that willingness to take an early, reduced benefit may help clients in other ways. Wealthy clients have usually been good earners and savers. Their attitudes toward money can lead them to delay activities and continue saving, but that approach can backfire in later life if health problems arise. Consequently, he often must push them to enjoy life and do things sooner rather than later. Claiming Social Security retirement benefits at age 62 can provide that impetus. "They get that extra $\$ 1,000, \$ 1,500$ in at age 62 , [and] maybe they're going to build that up for a great travel fund," he says. "Maybe they're going to go and enjoy things."

\section{IT MATTERS FOR MOST}

As Sachs points out, at some income level the retirement benefit, whether optimized or not, can become the equivalent of pocket change to the recipient. But according to the other advisers interviewed for this article, that attitude is uncommon among their wealthy clients. Helen Huntley, with Holifield Huntley Financial Advisers in St. Petersburg, Florida, says many of her firm's retired clients have a net worth between \$1 million and \$4 million. In her experience, the extra income from optimization matters to that cohort. "If you're talking about somebody who is [mega] wealthy, then it probably doesn't make any difference," she says. "But for typical people who are hoping to spend a good bit of money, like a couple hundred thousand a year, you're talking about more than $10 \%$ of that amount coming from Social Security. So, I don't see that that would be considered negligible."

The numbers support that attitude because the potential cumulative lifetime difference between optimal and suboptimal claiming strategies can be substantial, says William Reichenstein, CFA, at Baylor University in Waco, Texas. "So, I don't care if you have a billion dollars, you've got an asset out there that, if you work it right, can be worth $\$ 200,000$ more instead of less," he says. "It ought to be something that everybody is interested in."

Some retirees also have emotional reasons for pursuing optimization strategies. Harli Palme, CFA, with Parsec Financial in Asheville, North Carolina, points out that her firm's older clients, no matter how wealthy, have experienced 14 years of investment market volatility. As a result, they're still a "little gun shy" and want their money to last in an unknown future. Her experience has been that retired clients actively seek to maximize guaranteed incomes like Social Security because they know that investment results are variable.

A sense of fair play is another frequently cited reason, as some wealthy taxpayers believe they have paid more than enough to the government and want a payback. Jim Dew, president of Dew Wealth Management in Scottsdale, Arizona, says that among his retired clients, there is a strong feeling that "they put money into this program and they want to get their fair share out." Clients are pleased to learn about optimization strategies.

There's also an element of pleasant surprise at receiving money from a system that many boomers assumed would be bankrupt by now. Dew notes that in the late 1970s and early 1980s, advisers and clients often deliberately omitted the Social Security retirement benefit from clients' projected income sources on that assumption, particularly for baby boomers. Subsequent changes to the program have extended its projected lifespan, however, and the benefit's features have made it a much more attractive financial asset as well. 


\section{PLANNING STRATEGIES}

Optimization takes on added significance when advisers integrate benefit decisions into other aspects of clients' finances. For example, wealthy clients frequently accumulate large amounts in tax-deferred retirement plans. Once the clients reach age $70^{1} \frac{1}{2}$, required minimum distributions (RMDs) from those plans can create significant tax liabilities.

Daniel Johnson, financial adviser with Parsec Financial, has found that it's often advantageous for those clients to delay their Social Security retirement benefits and take withdrawals from their retirement plans before RMDs are required. The delayed start opens up optimization strategies, and when combined with other techniques, such as Roth IRA conversions, it can benefit clients' long-term tax planning. "By doing that [conversion] and combining it with deferred Social Security," he says, "you're not only growing your Social Security at $8 \%$ a year but you're also going ahead and taxefficiently taking out ahead of time these withdrawals that will have to eventually come out of your IRA or 401(k)."

Securing a higher guaranteed income for retired clients reduces the required rate of return from the portfolio as well, according to Johnson. Some clients respond to that change by reducing their portfolios' volatility. Others, such as those investing for a legacy, may feel more comfortable taking on more risk in search of higher returns because their required rate of return is lower.

\section{EARMARKS}

Clients feel good when they identify a specific need or goal that they can fund with their benefit, says Dew. He cites a couple that arranged to donate their optimized retirement benefits to a local charity. It's an informal, non-contractual gift, but the charity was pleased with the arrangement because it provides a reliable monthly contribution.

In another case Dew handled, clients who owned a business faced a significant liquidity problem because their combined estates were worth about $\$ 20$ million. They wanted liquidity in the estate to help their heirs with estate taxes and to avoid being forced to sell the business. The clients were also interested in helping a grandchild pay for college.

Both spouses were high earners and willing to delay collecting their individual retirement benefits. Dew advised the wife to take a spousal benefit from ages 66 to 70 so their individual benefits could continue growing until age 70. At that age, their combined monthly retirement benefit would be over $\$ 6,000$. They agreed to earmark $\$ 4,000$ of their benefit to fund a survivorship life insurance policy that is owned by an irrevocable life insurance trust. After both benefits start, the couple plans to use the remaining $\$ 2,000$ per month to help with their grandson's college room and board.

Johnson also cites a case in which the higher income resulting from optimization can influence clients' estate plans. In this instance, the clients decided to invest the

additional income in a Roth IRA that named a three-yearold client as beneficiary. Given the child's young age, the contributions can grow to a substantial amount.

\section{RUNNING THE NUMBERS}

The analytics behind claiming schemes are complicated, which is why many retirees opt for simple approaches, such as the breakeven calculation. Despite the complexity, there are several key factors advisers and retirees, particularly married couples, should consider, says Reichenstein, a codeveloper of the Social Security Solutions software. These include the ratio of the spouses' two primary insurance amounts (PIAs), their relative ages, and the life expectancy of the high-PIA spouse and low-PIA spouse.

Optimization usually involves delaying benefits to full retirement age or longer and using specific claiming strategies, such as taking a spousal benefit or file-and-suspend. Research supports the argument that a delayed start is beneficial for retirees, including most singles. Sita Nataraj Slavov and John B. Shoven have studied the benefits-timing decision considering the impact of mortality, program rules, and interest rates. In a July 2012 paper, they highlight several key points: (1) life expectancy has increased since the early 1960s; (2) rules changes have made delayed claiming more advantageous for married couples; and (3) real interest rates are near zero.

They conclude that with real rates close to zero, most households, including those with higher-than-average mortality rates, benefit from delaying Social Security retirement benefits. Higher interest rates modify that outcome slightly: "At real interest rates closer to their historical average, delay is not actuarially advantageous for single individuals with mortality that is substantially above average; however, for married couples, primary earners with above-average mortality can gain from delay by passing on a higher survivor benefit to their spouses."

Optimization strategies must evaluate multiple claiming strategies over potential starting dates between ages 62 to 70 for both married couples and single retirees. The permutations quickly create a very bushy decision tree. Reichenstein says that he once calculated there were over 70,000 claiming strategies available to a couple with an age difference of four years.

The advisers cited in this article use different tools for the analytics. Some outsource the calculations; others develop in-house spreadsheets or use free or low-cost web-based tools. Another option is to use one of the growing number

KEEP GOING

John B. Shoven and Sita Nataraj Slavov, "When Does It Pay to Delay Social Security? The Impact of Mortality, Interest Rates, and Program Rules," NBER Working Paper No. 18210 (July 2012): www.nber.org/papers/w18210.

John B. Shoven and Sita Nataraj Slavov, "Recent Changes in the Gains from Delaying Social Security," NBER Working Paper No. 19730 (August 2013): www.nber.org/papers/w19370. of commercial planning programs, such as Reichenstein's Social Security Solutions. Although the tools being used vary, the general consensus is that just like the less affluent, wealthy clients are interested in and appreciative of efforts to maximize their retirement benefits.

Ed McCarthy is a freelance financial writer in Pascoag, Rhode Island. 